\title{
Hubungan Motivasi dengan Faktor-Faktor yang Mempengaruhi Wanita Usia Subur dalam Melakukan Pap Smear di Kecamatan Cipondoh, Kota Tangerang Tahun 2016
}

\section{Relation between Motivation with Affecting Factors Productive Age Women to do Pap Smear in District of Cipondoh, Tangerang 2016}

\author{
Rayhana!, Hatfina Izzati ${ }^{1}$ \\ ${ }^{1}$ Program Studi Kedokteran, Fakultas Kedokteran dan Kesehatan, Universitas Muhammadiyah Jakarta \\ Fakultas Kedokteran dan Kesehatan, Universitas Muhammadiyah Jakarta, Jl. KH. Ahmad Dahlan \\ Cirendeu, Ciputat Tangerang Selatan 15419, mobile: 087771344661 \\ email: rayhanakuddah@yahoo.com
}

\begin{abstract}
Abstrak
Latar belakang: Kanker yang saat ini menjadi perhatian dunia dan megakibatkan tingginya angka kematian adalah kanker serviks. Data Globocan pada tahun 2013 menunjukkan prevalensi tertinggi kanker pada wanita di Indonesia adalah kanker serviks.Penyebabnyakarena kurangnya motivasi wanita untuk melakukan pemeriksaan Pap smear sehingga mengalami keterlambatan diagnosis yang mengakibatkan banyak wanita yang terdiagnosa kanker serviks dalam stadium lanjut. Penelitian ini bertujuan untuk mengetahui faktor-faktor yang mempengaruhi motivasi untuk melakukan Pap smear pada Wanita Usia Subur (WUS) di Kecamatan Cipondoh.
\end{abstract}

Metode: Metode pada penelitian ini adalah survey analitik dengan desain cross sectional. Sampel yang digunakan sebanyak 106 orang, dilaksanakan pada bulan Agustus sampai Oktober tahun 2016.I nstrumen yang digunakan adalah kuesioner.

Hasil: Terdapat hubungan antara motivasi melakukan Pap smear pada Wanita Usia Subur (WUS) dengan status ekonomi keluarga $(\mathrm{p}=0,019)$, jarak dari rumah ke pelayanan kesehatan $(\mathrm{p}=0,001)$ dan paparan informasi $(p=0,009) ;(p$ value $<0,05 ; \alpha=0,05)$. Motivasi untuk melakukan Pap smearsangat penting khususnya pada Wanita Usia Subur (WUS) untuk mencegah keterlambatan diagnosis sehingga dapat menurunkan angka kematian pada kanker serviks.

Simpulan: Diperlukan penyuluhan tentang kanker serviks, pemeriksaan Pap smeargratis secara berkala oleh tenaga kesehatan untuk meningkatkan motivasi wanita melakukan Pap smear.

Kata Kunci: Motivasi, wanita usia subur (WUS), kanker seviks, Pap smear 


\section{Abstract}

Background: A disease that attracts world's attention and result the high mortality rate is cervical cancer. According to Globocan in 2013 showed the highest prevalence of cancer in Indonesia is cervical cancer. One cause of the increased mortality rate is the lack of motivation of women to perform Pap smear so delayed diagnosis results in many women are diagnosed with cervical cancer in an advanced stage.This study investigates the factors that influence the motivation for Pap smears in productive age women in District of Cipondoh.

Methods: The method in this research is analytic survey with cross sectional design. The samples used were 106 people, conducted in August and October 2016. The instrument used was a questionnaire research.

Results: There was a relation between motivation to doPap smears in productive age women with the economic status of the family $(p=0,019)$, the distance from home to health services $(p=0,001)$ and information exposure $(p=0,009)$; ( $p$ value $<0.05 ; \alpha=0.05$ ). Motivation to perform Pap smear is very important, especially in productive age women to prevent delay in diagnosis that can reduce mortality in cervical cancer.

Conclusion: Required counseling about cervical cancer, Pap smear free regularly by health personnel to increase the motivation in productive age women.

Keywords: Motivation, productive age women, cervical cancer, Pap smear

\section{PENDAHULUAN}

Kanker serviks adalah salah satu penyakit kanker yang paling banyak terjadi pada kaum wanita. ${ }^{1}$ Fakta menunjukkan bahwa jutaan wanita di dunia terinfeksi virus HPV (Human Papilloma Virus), yang dianggap penyakit lewat hubungan seksual yang paling umum di dunia. ${ }^{2}$

Kanker serviks (leher rahim) merupakan masalah kesehatan yang penting bagi wanita di seluruh dunia dan merupakan penyebab kematian utama kanker pada wanita di negara-negara yang sedang berkembang. ${ }^{3}$ Menurut data Globocan pada tahun 2013 secara nasional prevalensi penyakit kanker pada penduduk semua umur di Indonesia pada tahun 2013 diperkirakan sekitar 347.792 orang dan dilaporkan bahwa prevalensi kanker pada wanita tertinggi adalah kanker serviks sebesar 98.692 penderita kemudian disusul oleh kanker payudara sebesar 61.682 penderita. ${ }^{4}$
Data rekam medik dari Rumah Sakit Umum Pusat Nasional Dr. Cipto Mangunkusumo menunjukkan bahwa jumlah penderita kanker serviks pada tahun 2007 sampai dengan 2011 yang melakukan pemeriksaan di poli rata-rata berjumlah 368 penderita pertahun, sedangkan yang rawat inap rata-rata berjumlah 259 pertahun, dan penderita pada tahun 2012 mulai bulan Januari sampai Oktober didapatkan data bahwa 327 penderita melakukan pemeriksaan di poli, artinya rata-rata penderita melakukan pemeriksaan sebanyak 27 penderita per bulan dan 275 penderita rawat inap, 303 diantaranya berusia antara 46-65 tahun. ${ }^{5}$

Insiden kematian meningkat akibat masyarakat enggan melakukan pemeriksaan, sehingga kanker terdiagnosa setelah dalam stadium lanjut. Faktor yang menyebabkan wanita tersebut mengalami keterlambatan diagnosis kanker serviks adalah karena tingkat pendidikan dan pengetahuan masyarakat yang rendah tentang 
penyakit serta skrining kanker serviks dan faktor penyebab lain adalah multiparitas, penggunaan kontrasepsi hormonal, merokok, peyakit menular seksual, dan faktor nutrisi. Penelitian di Turki pada tahun 2007 didapatkan hasil dari 237 responden bahwa $69,6 \%$ tidak bekerja, disebabkan karena pendidikan mereka rendah dan tidak melanjutkan jenjang yang lebih tinggi, sehingga berdampak terhadap pengetahuan dan motivasi seseorang dalam melakukan skrining. ${ }^{5}$

Kurangnya motivasi ini juga disebabkan oleh kemampuan petugas kesehatan dalam menyampaikan dan memberikan informasi pencegahan dini kanker serviks yang belum merata dan tersosialisasi dengan baik. Selain itu faktor sosial ekonomi, masyarakat dengan sosial ekonomi yang rendah, malas untuk melakukan pemeriksaan ke pelayanan kesehatan, karena mereka beranggapan biaya pengobatan mahal dan akses yang tidak terjangkau, terlalu jauh ke pelayanan kesehatan dan rasa takut pada penderita, sehingga mereka tidak ada motivasi untuk melakukan skrining kanker serviks yang berdampak terhadap semakin meningkatnya penderita kanker serviks dengan stadium lanjut. ${ }^{5}$

Berdasarkan penelitian Fitri (2004) tentang tingkat pengetahuan perempuan mengenai kanker serviks di Kelurahan Kukusan Beji Depok, didapatkan hasil bahwa 21,6\% responden wanita dewasa menengah memiliki tingkat pengetahuan tinggi tentang kanker serviks, 24,3\% memiliki tingkat pengetahuan sedang dan 50\% memiliki tingkat pengetahuan rendah. Penelitian diatas terlihat bahwa masih rendahnya pengetahuan masyarakat tentang pemeriksaan Pap smear. ${ }^{7}$

Pemeriksaan apusan Pap smearsaat ini merupakan suatu keharusan bagi wanita, sebagai sarana pencegahan dan deteksi dini kanker serviks. Pemeriksaan ini diharuskan untuk setiap wanita yang sudah menikah sampai dengan umur kurang lebih 65 tahun bila dalam dua kali pemeriksaan apusan Pap smearterakhir negatif dan tidak pernah memiliki riwayat hasil pemeriksaan abnormal sebelumnya. Pemeriksaan ini dilaksanakan secara berkala, minimal dilakukan satu tahun sekali, walaupun tidak mempunyai keluhan pada organ saluran genital, karena kanker serviks pada stadium awal biasanya tanpa keluhan. Pemeriksaan Pap smearsecara berkala diharapkan dapat menemukan kanker serviks secara dini ataupun lesi pre kanker yang belum menimbulkan suatu gejala klinis sehingga dapat menurunkan angka kejadian morbiditas dan mortalitas kanker serviks. ${ }^{8}$

Penelitian ini bertujuan untuk mengetahui faktor-faktor yang mempengaruhi motivasi untuk melakukan Pap smear pada Wanita Usia Subur (WUS) di Kecamatan Cipondoh.

\section{METODE PENELITIAN}

Tempat penelitian ini dilakukan di warga sekitar Kecamatan Cipondoh, Kota Tangerang.Waktu penelitian dilakukan pada bulan Agustus sampai dengan Oktober tahun 2016. Waktu penelitian ini dihitung mulai dari pengajuan judul ke dosen pembimbing dan penyusunan proposal, sampai dengan tahap pelaksanaan yang terdiri dari proses perizinan penelitian, pengumpulan data, pengolahan hasil dan penyusunan laporan penelitian.Metode yang digunakan dalam penelitian ini adalah survey analatic karena peneliti mencoba menganalisis adanya hubungan antar variabel.Penelitian ini menggunakan pendekatan cross sectional, dimana tiap subjek penelitian hanya diobservasi sekali saja untuk pengumpulan data yang dibutuhkan dalam 
penelitian.Populasi dalam penelitian ini adalah seluruh wanita usia subur yang berusia 15-49 tahun yang berada di wilayah Kecamatan Cipondoh, Kota Tangerang pada tahun 2016.Sampel dalam penelitian ini diambil secara acak sederhana (Simple Random Sampling), yang berjumlah 106 wanita usia subur.Instrumen atas pengumpulan data yang digunakan dalam penelitian ini adalah kuesioner.

\section{HASIL DAN PEMBAHASAN}

Responden yang mengisi kuesioner yang telah disiapkan oleh peneliti adalah 106 orang. Kemudian, dari kuesioner responden tersebut didapatkan gambaran karakteristik yang dibagi dalam dua kategori, yaitu kategori intrinsik (usia, tingkat pendidikan, pengetahuan tentang kanker serviks, pekerjaan, status ekonomi) dan kategori ekstrinsik (jarak ke pelayanan kesehatan, terpaparnya dengan informasi, dukungan sosial).

Tabel 1 menunjukkan bahwa responden yang mempunyai motivasi tinggi sebanyak 65 responden $(61,3 \%)$ dan responden dengan motivasi rendah sebanyak 41 responden $(38,7 \%)$.Responden yang berusia $<36$ tahun yaitu 50 responden $(47,2 \%)$ dan responden yang berusia $\geq 36$ tahun yaitu 56 responden (52,8\%). Tingkat pendidikan responden terbanyak adalah Perguruan Tinggi sebanyak 63 orang (59,4\%) dan SMA sebanyak 32 responden $(30,2 \%)$ sehingga tingkat pendidikan responden dikategorikan tinggi, sedangkan tingkat pendidikan rendah yaitu SD sebanyak 5 responden $(4,7 \%)$ dan SMP sebanyak 6 responden (5,7\%). Sehingga untuk responden yang berpendidikan rendah 11 responden $(10,4 \%)$ dan tinggi 95 responden $(89,6 \%)$.Responden yang mempunyai tingkat pengetahuan kurang sebanyak 51 responden
$(48,1 \%)$ dan responden yang mempunyai tingkat pengetahuan baik sebanyak 55 responden (51,9\%).Responden yang tidak bekerja yang banyak berasal dari ibu rumah tangga lebih sedikit yakni 37 responden, sedangkan responden yang bekerja yakni 69 responden $(65,1 \%)$. Status ekonomi sedang merupakan responden terbanyak yaitu 43 responden $(40,6 \%)$, status ekonomi tinggi 34 responden $(32,1 \%)$ dan status ekonomi rendah 29 responden $(27,4 \%)$.

Hasil penelitian juga menunjukkan bahwa jarak dekat dari pelayanan kesehatan merupakan responden tertinggi yaitu 83 responden $(78,3 \%)$ dan jarak yang jauh dari pelayanan kesehatan yaitu 23 responden (21,7\%).menunjukkan bahwa terpaparnya responden dengan informasi yaitu sebanyak 87 responden (82,1\%), sedangkan yang tidak mendapat terpapar dengan informasi sebanyal 19 responden (17,9\%). menunjukkan bahwa dukungan sosial pada responden yang terbanyak yaitu yang mendapatkan dukungan sosial tinggi sebanyak 53 responden (50\%) dan yang mendapat dukungan sosial rendah sebanyak 53 responden $(50 \%)$.

Tabel 2 menunjukkan hasil analisis hubungan antara motivasi dengan usia, hasil uji statistik diperoleh nilai $\mathrm{p}=0,144, \alpha=0,05$ maka dapat disimpulkan bahwa tidak terdapat hubungan yang bermakna antara motivasi dengan usia dalam melakukan Pap smear. Hasil analisis diperoleh nilai korelasi $(\mathrm{OR})=1,797$ dengan $\mathrm{CI}$ (95\%): 0,8-3,6.Hubungan antara motivasi dengan tingkat pendidikan, hasil uji statistik diperoleh nilai $\mathrm{p}=0,085, \alpha=0,05$ maka dapat disimpulkan tidak terdapat hubungan yang bermakna antara motivasi dengan tingkat pendidikan WUS dalam melakukan Pap smear. Dari hasil analisis diperoleh nilai korelasi (OR) yaitu sebesar 3,7 dengan CI 
(95\%): 0,8-18,1.Analisis hubungan antara motivasi dengan pengetahuan, diperoleh hasil uji statistik diperoleh nilai $\mathrm{p}=0,364, \alpha=0,05$ maka dapat disimpulkan tidak terdapat hubungan yang bermakna antara motivasi dengan pengetahuan WUS dalam melakukan Pap smear. Dari hasil analisis diperoleh nilai korelasi (OR) yaitu sebesar 1,437 dengan CI (95\%): 0,6-3,2.

Pada tabel tersebut dapat dilihat hasil uji statistik hubungan motivasi dengan pekerjaan diperoleh nilai $\mathrm{p}=0,48, \alpha=0,05$ maka dapat disimpulkan tidak ada hubungan yang bermakna antara motivasi dengan pekerjaan WUS dalam melakukan Pap smear. Dari hasil analisis diperoleh nilai korelasi (OR) yaitu sebesar 1,341 dengan CI (95\%): 0,59-3,02. Hubungan motivasi dengan status ekonomi menunjukkan hasil uji statistik diperoleh $\mathrm{p}=0,010$ atau $\mathrm{p}<0,05, \alpha=0,05$ maka dapat disimpulkan terdapat hubungan yang bermakna antara motivasi dengan status ekonomi WUS dalam melakukan Pap smear. Dari hasil analisis diperoleh korelasi (OR) yaitu sebesar 3,13 dengan CI (95\%): 1,3-7,6 yang artinya responden yang berstatus ekonomi sedang-tinggi memiliki peluang 3,13 atau 3 kali lebih besar mempunyai motivasi tinggi untuk melakukan Pap smeardibandingkan responden yang berstatus ekonomi rendah.

Berdasarkan tabel 2 dapat dilihat hubungan motivasi dengan jarak ke pelayanan kesehatanmenunjukkanhasil uji statistik nilai $\mathrm{p}=$ 0.001 atau $\mathrm{p}<0,05, \alpha=0,05$ maka dapat disimpulkan bahwa terdapat hubungan yang bermakna antara motivasi dengan jarak pada WUS dalam melakukan Pap smear. Dari hasil analisis diperoleh nilai korelasi (OR) yaitu sebesar 0,189 dengan CI (95\%): 0,07-0,5 yang artinya responden yang jaraknya dekat dari rumah ke pelayanan kesehatan memiliki peluang 0,189 atau 2 kali lebih besar mempunyai motivasi tinggi melakukan Pap smeardibandingkan responden dengan jarak yang jauh dari rumah ke pelayanan kesehatan dengan interval/tingkat kepercayaan 95\% antara 0,07 sampai 0,5.Hubunganantara motivasi dengan paparan informasi bahwa hasil uji statistik diperoleh nilai $\mathrm{p}=0,058, \alpha=0,05$ maka dapat disimpulkan tidak ada hubungan yang bermakna antara motivasi dengan paparan informasi pada WUS dalam melakukan Pap smear. Dari hasil analisis diperoleh nilai korelasi (OR) yaitu sebesar 0,383 dengan CI (95\%): 0,14-1,05.

Tabel 2 menunjukkan hubungan motivasi dengan dukungan sosial didapat hasil uji statistik nilai $\mathrm{p}=0,003, \alpha=0,05$ maka dapat disimpulkan terdapat hubungan yang bermakna antara motivasi dengan dukungan sosial pada WUS dalam melakukan Pap smear. Dari hasil analisis diperoleh korelasi (OR) yaitu sebesar 3,446 dengan CI (95\%): 1,5-7,9 yang artinya responden yang mendapat dukungan sosial tinggi memiliki peluang 3,446 atau 4 kali lebih besar mempunyai motivasi tinggi untuk melakukan Pap smeardibandingkan responden yang mendapat dukungan sosial rendah. 
Tabel 1. Rekapitulasi Hasil Analisis Univariat

\begin{tabular}{|c|c|c|}
\hline Variabel & Jumlah (n) & Persentase $(\%)$ \\
\hline \multicolumn{3}{|l|}{ Motivasi } \\
\hline - Rendah & 41 & 38,7 \\
\hline - Tinggi & 65 & 61,3 \\
\hline \multicolumn{3}{|l|}{ Usia } \\
\hline$-<36$ & 50 & 47,2 \\
\hline$-\geq 36$ & 56 & 52,8 \\
\hline \multicolumn{3}{|l|}{ Tingkat Pendidikan } \\
\hline$-\mathrm{SD}$ & 5 & 4,7 \\
\hline - SMP & 6 & 5,7 \\
\hline - SMA & 32 & 30,2 \\
\hline - PT & 63 & 59,4 \\
\hline \multicolumn{3}{|l|}{ Tingkat Pengetahuan } \\
\hline - Kurang & 51 & 48,1 \\
\hline - Baik & 55 & 51,9 \\
\hline \multicolumn{3}{|l|}{ Pekerjaan } \\
\hline - Tidak Bekerja & 37 & 34,9 \\
\hline - Bekerja & 69 & 65,1 \\
\hline \multicolumn{3}{|l|}{ Status Ekonomi } \\
\hline - Rendah & 29 & 27,4 \\
\hline - Sedang & 43 & 40,6 \\
\hline - Tinggi & 34 & 32,1 \\
\hline \multicolumn{3}{|c|}{ Jarak ke Pelayanan Kesehatan } \\
\hline - Dekat & 83 & 78,3 \\
\hline - Jauh & 23 & 21,7 \\
\hline \multicolumn{3}{|l|}{ Paparan Informasi } \\
\hline - Ya & 19 & 17,9 \\
\hline - Tidak & 87 & 82,1 \\
\hline \multicolumn{3}{|l|}{ Dukungan Sosial } \\
\hline - Rendah & 53 & 50 \\
\hline - Tinggi & 53 & 50 \\
\hline
\end{tabular}


Tabel 2. Analisis Bivariat

\begin{tabular}{|c|c|c|c|c|c|c|c|c|c|c|}
\hline \multirow{3}{*}{\multicolumn{2}{|c|}{ Variabel }} & \multicolumn{4}{|c|}{ Motivasi } & \multirow{2}{*}{\multicolumn{2}{|c|}{ Total }} & \multirow{3}{*}{ p-value } & \multirow{3}{*}{ CI $(95 \%)$} & \multirow{3}{*}{ OR } \\
\hline & & \multicolumn{2}{|c|}{ Rendah } & \multicolumn{2}{|c|}{ Tinggi } & & & & & \\
\hline & & $\mathrm{N}$ & $\%$ & $\mathrm{~N}$ & $\%$ & $\mathrm{~N}$ & $\%$ & & & \\
\hline \multicolumn{11}{|c|}{ Usia } \\
\hline- & $<36$ tahun & 27 & 54 & 23 & 46 & 50 & 100 & \multirow{2}{*}{0,144} & \multirow{2}{*}{$0,8-3,9$} & \multirow{2}{*}{1,798} \\
\hline- & $\geq 36$ tahun & 38 & 68 & 18 & 32 & 56 & 100 & & & \\
\hline \multicolumn{11}{|c|}{ Tingkat Pendidikan } \\
\hline & Rendah & 4 & 36,36 & 7 & 63,63 & 11 & 100 & \multirow{2}{*}{0,868} & \multirow{2}{*}{$0,3-4,0$} & \multirow{2}{*}{1,116} \\
\hline & Tinggi & 37 & 38,95 & 58 & 61,05 & 95 & 100 & & & \\
\hline \multicolumn{11}{|c|}{ Pengetahuan } \\
\hline- & Kurang & 22 & 43,14 & 29 & 56,86 & 51 & 100 & \multirow{2}{*}{0,364} & \multirow{2}{*}{$0,6-3,2$} & \multirow{2}{*}{1,437} \\
\hline & Baik & 19 & 34,55 & 36 & 65,45 & 55 & 100 & & & \\
\hline \multicolumn{11}{|c|}{ Pekerjaan } \\
\hline & Tidak bekerja & 16 & 64,86 & 21 & 35,14 & 37 & 100 & \multirow{2}{*}{0,48} & \multirow{2}{*}{$0,59-3,02$} & \multirow{2}{*}{1,341} \\
\hline & Bekerja & 25 & 53,62 & 44 & 46,38 & 69 & 100 & & & \\
\hline \multicolumn{11}{|c|}{ Status Ekonomi } \\
\hline & Rendah & 17 & 58,62 & 12 & 41,38 & 29 & 100 & \multirow{2}{*}{0,010} & \multirow{2}{*}{$1,3-7,6$} & \multirow{2}{*}{3,13} \\
\hline & Sedang-Tinggi & 24 & 31,17 & 53 & 68,83 & 77 & 100 & & & \\
\hline \multicolumn{11}{|c|}{ Jarak } \\
\hline - & Jauh & 16 & 69,57 & 7 & 30,43 & 23 & 100 & \multirow{2}{*}{0,001} & 00705 & 0,189 \\
\hline & Dekat & 25 & 30,12 & 58 & 69,88 & 83 & 100 & & $0,0 /-0,3$ & \\
\hline Papa & an Informasi & & & & & & & & & \\
\hline- & Tidak & 11 & 84,21 & 8 & 15,79 & 19 & 100 & 0058 & $014-105$ & 0383 \\
\hline - & Ya & 30 & 51,72 & 57 & 48,28 & 87 & 100 & 0,058 & $0,14-1,02$ & 0,383 \\
\hline Duk & ngan Sosial & & & & & & & & & \\
\hline - & Rendah & 28 & 52,83 & 25 & 47,17 & 53 & 100 & 0003 & $15-70$ & 3446 \\
\hline- & Tinggi & 13 & 24,53 & 40 & 75,47 & 53 & 100 & 0,003 & (1, & $J,+40$ \\
\hline
\end{tabular}

Hasil penelitian menunjukkan bahwa motivasi responden dalam melakukan Pap smear adalah tinggi yaitu 65 responden $(61,3 \%)$ sedangkan motivasi tinggi yaitu 41 responden $(38,7 \%)$. Secara teori terdapat tiga hal penting yang dapat membuat seseorang termotivasi yaitu hubungan antara kebutuhan, dorongan dan tujuan. ${ }^{9}$ Oleh karena itu, dapat dipastikan motivasi akan timbul apabila seseorang merasa memiliki kebutuhan yang harus terpenuhi. Jika tidak ada kebutuhan, maka tidak mungkin seseorang terdorong untuk melakukan sesuatu dalam mencapai tujuan.

Hasil penelitian menunjukkan rata-rata responden memiliki motivasi tinggi.Hal ini dimungkinkan karena responden merasa bahwa dirinya memiliki kebutuhan untuk melakukan pemeriksaan Pap smear. Pada umumnya, masyarakat memiliki kecendrungan merasa perlu untuk memeriksakan diri ke pelayanan kesehatan apabila secara fisik penyakit tersebut sudah tampak ataupun sudah dirasakan keluhannya.Sementara kanker serviks tidak menimbulkan gejala atau belum terasa keluhannya secara fisik apabila masih dalam stadium awal. Oleh karena itu, banyak penderita kanker serviks yang ditemukan sudah dalam keadaan stadium lanjut, karena pada stadium tersebut keluhankeluhan sudah muncul.

Teori motovasi berdasarkan teori kebutuhan menurut Maslow, salah satu bagian kebutuhan yang paling dasar yaitu terbebas dari rasa sakit. Apabila rasa sakit muncul ataupun dirasakan oleh seseorang maka kecendrungan 
orang tersebut akan mencari tahu dan mencari pertolongan untuk menghilangkan rasa sakitnya tersebut. Sedangkan, pada kanker serviks pada stadium awal biasanya tidak disertai keluhan fisik.

Hubungan Usia dengan Motivasi Melakukan Pap Smearmenunjukkan rata-rata usia responden adalah 36,35 tahun, dengan rentang usia berdasarkan teori Wania Usia Subur (WUS) yaitu 15-45 tahun. Usia 36 tahun termasuk dalam kategori usia dewasa, walaupun ada beberapa responden yang berusia di bawah 36 tahun, namun responden yang peneliti dapatkan masih dalam kategori usia dewasa.

Dari hasil penelitian ini didapatkan bahwa usia tidak berpengaruh terhadap motivasi melakukan Pap smear. Hal tersebut mungkin dikarenakan tidak adanya kesadaran dalam diri sendiri untuk melakukan Pap smear.Hal ini juga disebabkan karena merasa tidak ada keluhan, takut mengetahui adanya kelainan, merasa pemeriksaan Pap smear itu tidak penting ataupun malu untuk melakukannya. ${ }^{5}$

Dari penelitian yang sebelumnya menyebutkan usia terbanyak responden yang terkena kanker serviks adalah 21-24 tahun $(44,8 \%) .{ }^{10}$ Dan usia ini masih berada dalam rentang usia penelitian penulis yaitu 15-49 tahun. Hasil penelitian penulis juga tidak berbeda dengan hasil penelitian lain yang menyatakan tidak ada perbedaan motivasi melakukan Pap smearantara usia responden di Kelurahan Tugu Depok. ${ }^{7}$ Dan didukung oleh hasil penelitian yang menyatakan bahwa tidak ada hubungan antara umur dengan motivasi perempuan untuk melakukan pemeriksaan skrining kanker serviks di Puskesmas Cimanggis, Kota Depok. ${ }^{5}$ Dari hasil penelitian lain juga menyatakan usia tidak berpengaruh terhadap motivasi mencari pengobatan di Poli Kebidanan. ${ }^{7}$ Dan juga didukung oleh hasil penelitian yang menunjukkan tidak adanya perbedaan yang bermakna antara umur responden dengan motivasi. ${ }^{11}$

Hal tersebut menunjukkan bahwa semakin tua usia responden tidak berarti motivasi atau perilaku serta keinginannya semakin besar walaupun sebenarnya seseorang dengan usia yang lebih tua akan lebih matang dalam mengambil suatu sikap atau keputusan, akan tetapi karena kurangnya kesadaran diri dalam hal menjaga kesehatan serta mencegah suatu penyakit, maka orang tersebut tidak akan termotivasi untuk melakukan Pap smear.

Hubungan Tingkat Pendidikan dengan Motivasi Melakukan Pap smearhasil penelitian menunjukkan kelompok yang berpendidikan tinggi adalah paling banyak. Dan hasil penelitian ini menunjukkan bahwa tidak ada hubungan yang bermakna antara tingkat pendidikan dengan motivasi melakukan Pap smear. Hal ini juga didukung oleh penelitian lain yang menunjukkan bahwa tidak ada perbedaan melakukan Pap smearantara tingkat pendidikan rendah dan tinggi.7Serta didukung oleh hasil tesis pada variabel pendidikan menunjukkan bahwa tidak ada hubungan antara antara pendidikan dengan motivasi perempuan untuk melakukan pemeriksaan skrining kanker serviks. ${ }^{5}$ Dan hal ini juga didukung oleh penelitian yang dilakukan pada tahun 2008, yang menujukkan bahwa tidak ada hubungan yang bermakna antara tingkat pendidikan dengan motivasi untuk melakukan perawatan daerah kewanitaan. ${ }^{12}$

Menurut Herzbeg, pendidikan dapat memacu peningkatan diri seseorang. ${ }^{7}$ Jika dihubungkan dengan motivasi, pendidikan tinggi akan lebih termotivasi daripada pendidikan 
rendah. Namun, hasil penelitian ini tidak sesuai dengan penelitian yang dilakukan Logan tahun 2011 terhadap perempuan di United Kingdom, yang menjelaskan bahwa faktor yang mendorong perempuan untuk melakukan pemeriksaan skrining kanker serviks adalah tingkat pendidikan seseorang, semakin tinggi tingkat pendidikan seseorang maka semakin termotivasi pula perempuan tersebut untuk melakukan pemeriksaan skrining kanker serviks. ${ }^{5}$

Oleh karena itu, hasil penelitian ini tidak sesuai dengan teori Herzbeg dan penelitian yang dilakukan oleh Logan, dimungkinkan karena tidak tersedianya fasilitas pemeriksaan Pap smear di Puskesmas terdekat yang menyelenggarakan secara rutin dan berkala. Atau mungkin dapat juga karena semakin tinggi pendidikan seseorang maka semakin takut orang tersebut untuk melakukan Pap smear:Takut disini diartikan takut akan penyakitnya diketahui sehingga nantinya akan berdampak pada aktivitas, pekerjaan dan status ekonomi. Dari hasil penelitian lain menjelaskan bahwa salah satu alasan yang paling banyak seseorang enggan untuk melakukan pemeriksaan Pap smear adalah karena malu, dan alasan-alasan lain karena takut akan hasilnya, mahal, merasa tidak butuh dan tidak nyaman. ${ }^{13}$

Hubungan Pengetahuan dengan Motivasi Melakukan Pap smearhasil penelitian menunjukkan tidak ada hubungan yang bermakna antara pengetahuan dengan motivasi melakukan Pap smear. Hasil penelitian ini didukung oleh hasil tesis yang menyatakan tidak terdapat hubungan yang signifikan antara pengetahuan dengan motivasi perempuan. ${ }^{5}$ Dan dalam penelitian lain juga menunjukkan tidak ada perbedaan antara tingkat pengetahuan tinggi ataupun tingkat pengetahuan rendah terhadap motivasi ibu untuk melakukan
IMD (Inisiasi Menyusui Dini). ${ }^{11}$ Namun, hal ini bertentangan dengan hasil penelitian yang menunjukkan adanya perbedaan motivasi melakukan Pap smearantara responden yang mempunyai pengetahuan kurang dan baik. ${ }^{7}$

Dari hasil penelitian yang penulis lakukan bahwa sebagian besar responden yang mendapat pengetahuan tentang kanker serviks ataupun Pap smearmereka dapatkan dari TV, internet, radio, koran, majalah, brosur, seminar dan penyuluhan yang dilakukan oleh dokter atau tenaga kesehatan lainnya. Oleh karena itu, menurut peneliti, pengetahuan tidak hanya diperoleh dengan pendidikan formal, tetapi bisa juga didapatkan dari hal-hal tersebut, dan semakin banyak memperoleh pengetahuan tentang kanker serviks ataupun Pap smearmaka semakin besar motivasi untuk melakukan Pap smear.

Hal ini berhubungan dengan penelitian yang penulis lakukan antara tingkat pendidikan dengan motivasi. Tingkat pendidikan rata-rata responden adalah tinggi yaitu 95 responden $(89,62 \%)$, tetapi bukan berarti setiap pendidikan itu mengajarkan tentang kesehatan terutama mengenai kanker serviks ataupun Pap smear. Walaupun pada kenyataannya, hasil uji statistik yang penulis dapatkan menunjukkan tidak ada hubungan yang bermakna antara pengetahuan ataupun tingkat pendidikan terhadap motivasi melakukan Pap smear.

Jadi, walaupun pendidikan tinggi tetapi didalamnya tidak diajarkan materi tentang kesehatan (kanker serviks atau Pap smear), maka hasil penelitian yang penulis dapatkan menunjukkan tingkat pengetahuan rendah walaupun rata-rata sebagian besar responden berpendidikan tinggi sehingga motivasi yang 
didapatkan juga sebagian besar adalah rendah $(57,55 \%)$.

Hubungan Pekerjaan dengan Motivasi Melaukan Pap smearhasil uji statistik pada variabel pekerjaan menunjukkan bahwa tidak ada hubungan yang bermakna antara pekerjaan dengan motivasi melakukan Pap smear.Hasil penelitian ini didukung oleh tesis yang menyatakan bahwa tidak ada hubungan antara pekerjaan dengan motivasi perempuan untuk melakukan pemeriksaan skrining kanker serviks. Hasil ini juga sesuai dengan penelitian yang dilakukan oleh Logan (2011), yang menjelaskan bahwa perempuan yang tidak memiliki pekerjaan, belum tentu persepsi dan motivasi mereka tentang pemeriksaan skrining kanker serviks rendah. ${ }^{5}$

Sedangkan, menurut Zacler, pekerjaan erat kaitannya dengan tingkat penghasilan dan lingkungan kerja, dimana apabila tingkat penghasilan tinggi maka pemanfaatan pelayanan kesehatan dan pencegahan terhadap penyakit juga akan meningkat, jika dibandingkan dengan penghasilan rendah yang akan berdampak pada kurangnya pemanfaatan pelayanan kesehatan dalam hal pemeliharaan kesehatan karena ketidakmampuannya dalam daya beli obat ataupun transportasi untuk mengunjungi pusat pelayanan kesehatan. ${ }^{7}$

Hubungan status ekonomi dengan motivasi melakukan Pap smearuji statistik yang penulis dapatkan menunjukkan bahwa terdapat hubungan yang bermakna antara status ekonomi dengan motivasi melakukan Pap smear, dengan peluang 3 kali lebih besar pada status ekonomi sedang-tinggi untuk memiliki motivasi melakukan Pap smeardibandingkan dengan status ekonomi rendah. Hasil penelitian ini didukung oleh hasil analisis statistik yang menunjukkan bahwa ada perbedaan motivasi melakukan pemeriksaan Pap smear antara status ekonomi rendah, sedang, tinggi. ${ }^{7}$ Namun hal ini bertentangan dengan hasil tesis yang menunjukkan bahwa tidak ada hubungan antara penghasilan dengan motivasi perempuan untuk melakukan pemeriksaan skrining kanker serviks. ${ }^{5}$

Status ekonomi yang tinggi memungkinkan anggota keluarga untuk memperoleh kebutuhan yang lebih baik seperti pendidikan, kesehatan, dan sebagainya. Demikian sebaliknya, pada status ekonomi rendah akan memiliki hambatan dalam memenuhi kebutuhan-kebutuhannya. Maka dapat disimpulkan bahwa status ekonomi sangat menentukan seseorang untuk lebih meningkatkan kesehatannya menjadi lebih baik terutama untuk melakukam Pap smear secara rutin.

Walaupun saat ini telah diterapkannya Badan Penyelanggara Jaminan Keshatan (BPJS) namun hal tersebut masih banyak kekurangankekurangan seperti keikutsertaan penduduk yang belum merata diseluruh pelosok Indonesia, pelayanan yang terkesan lambat, fasilitas yang masih kurang, serta harus mendapat rujukan terlebih dahulu untuk mendapat pelayanan kesehatan yang lebih baik sehingga membuat sebagian orang malas ataupun belum terdaftar untuk menjadi peserta BPJS karena prosesnya terkesan rumit ataupun dipersulit. ${ }^{14}$

Hubungan jarak ke tempat pelayanan kesehatandengan motivasi melakukan Pap smearhasil penelitian ini menunjukkan bahwa terdapat hubungan yang bermakna antara jarak dengan motivasi melakukan Pap smear, dengan peluang memiliki motivasi 0,2 kali lebih besar pada responden yang jarak rumahnya lebih dekat dari sarana untuk melakukan Pap 
smeardibandingkan responden yang jarak rumahnya jauh dari sarana atau tempat pelayanan kesehatan untuk melakukan Pap smear.

Tidak semua puskesmas menyelenggarakan pemeriksaan Pap smear.Pemeriksaan ini ada di rumah sakit atau beberapa pelayanan khusus, sehingga sulit terjangkau oleh masyarakat untuk mengakses tempat pelayanan kesehatan tersebut pada masyarakat yang bertempat tinggal jauh dari institusi yang menyelenggarakan pemeriksaan Pap smear:Namun, pada penelitian lain menyimpulkan tidak terdapat hubungan yang bermakna antara jarak dengan motivasi. ${ }^{5}$

Menurut Lawrence Green salah satu faktor utama yang mempengaruhi perilaku adalah faktor pendukung yaitu tersedianya fasilitas, sarana dan prasarana pelayanan kesehatan, serta kemudahan untuk mengakses tempat pelayanan kesehatan tersebut sebagai upaya untuk mendukung atau menyediakan fasilitas, sehingga muncul perilaku/motivasi seseorang untuk memenuhi kebutuhannya. ${ }^{5}$ Akan tetapi bila biaya pemeriksaan mahal dan masyakat tidak mampu untuk menjangkaunya, hal ini juga akan mempengaruhi perilaku/motivasi seseorang untuk memenuhi kebutuhannya terutama dalam hal kesehatan. Adanya hubungan antara jarak dengan motivasi melakukan Pap smear, dimungkinkan karena seseorang jaraknya dekat dengan pelayanan kesehatan merasa waktu yang dibutuhkanpun lebih sedikit dan biaya transportasipun sedikit untuk mencapai ke tempat pelayanan kesehatan tersebut karena sebagian besar responden sibuk bekerja yaitu sebanyak 69 responden $(65,1 \%)$.

Hubungan paparan informasi yang pernah didapatkan responden tentang kanker serviks atau Pap smear dengan motivasi melakukan Pap smear hasil penelitian menunjukkan tidak ada hubungan yang bermakna antara paparan informasi dengan motivasi melakukan Pap smear. Hasil penelitian ini didukung oleh hasil tesis yang menunjukan tidak adanya hubungan antara paparan informasi dengan motivasi perempuan untuk melakukan skrining kanker serviks. ${ }^{5}$

Dari hasil kuesioner yang diberikan ratarata responden yang terpapar dengan sumber informasi tentang kanker serviks ataupun Pap smear yaitu bersumber dari TV, internet, radio, majalah, koran, brosur, seminar dan penyuluhan yang dilakukan oleh dokter atau tenaga kesehatan lainnya.

Hubungan dukungan sosial dengan motivasi melakukan Pap smear hasil penelitian menunjukkan bahwa terdapat hubungan yang bermakna antara dukungan sosial dengan motivasi melakukan Pap smear. Hasil penelitian ini didukung dengan penelitian yang dilakukan oleh White dkk, di Zambia pada tahun 2012 terhadap 60 wanita tentang motivasi dan pengalaman mereka saat melakukan pemeriksaan skrining kanker serviks untuk mencegah terjadinya kanker serviks didapatkan hasil bahwa dukungan dari keluarga sangat mempengaruhi perempuan untuk termotivasi melakukan pemeriksaan skrining kanker serviks. ${ }^{5} \mathrm{Hal}$ ini sejalan dengan Notoatmodjo, yang menyatakan bahwa faktor lingkungan dapat mempersulit motivasi seseorang untuk berperilaku hidup sehat jika lingkungan keluarganya tidak mendukung perilaku tersebut. ${ }^{7}$

Namun, hasil ini tidak sesuai dengan hasil tesis yang menunjukkan bahwa tidak terdapat hubungan yang signifikan antara dukungan sosial dengan motivasi perempuan untuk melakukan pemeriksaan skrining kanker serviks. ${ }^{5}$ Dan juga penelitian lain yang menyebutkan tidak ada

Vol. 1 No.4Agustus 2017 
hubungan yang bermakna antara motivasi dengan lingkungan yang berada disekitar responden. ${ }^{15}$ Serta penelitian lain yang juga menunjukkan tidak adanya hubungan antara dukungan sosial dengan motivasi pria melakukan vesektomi. ${ }^{16}$ Perbedaan hasil penelitian ini dimungkinkan karena perbedaan tempat penelitian serta jumlah sampel yang digunakan dalam penelitian.

\section{SIMPULAN}

Berdasarkan hasil penelitian yang dilakukan di Kecamatan Cipondoh pada Wanita Usia Subur (WUS), maka penulis membuat kesimpulan secara keseluruhan, responden yang memiliki motivasi tinggi untuk melakukan Pap smear pada Wanita Usia Subur (WUS).Terdapat hubungan yang bermakna antara motivasi dengan status ekonomi, jarak rumah ke pelayanan kesehatan, dan dukungan social pada Wanita Usia Subur (WUS) dalam melakukan Pap smear.

Diharapkan penelitian ini dapat dijadikan sumber evaluasi dalam program kerja untuk menjadikan penduduk di Kecamatan Cipondoh lebih sadar akan pentingnya kesehatan serta pencegahannya khususnya dalam membangun motivasi para wanita usia subur di sekitar Kecamatan Cipondoh untuk melakukan pemeriksaan Pap smear secara rutin untuk deteksi secara dini kanker serviks sehingga dapat menurunkan angka morbiditas dan mortalitas kanker serviks.

\section{DAFTAR PUSTAKA}

1. Tilong, Adi S. 2012. Bebas Dari Ancaman Kanker Serviks. Yogyakarta: Flash Book: Cetakan Pertama.
2. Wijaya, Delia. 2010. Pembunuh Ganas Itu Bernama Kanker Serviks. Yogyakarta: Sinar Kejora.

3. Notodiharjo, Riano. 2002. Reproduksi, Kontrasepsi, dan Keluarga Berencana. Yogyakarta: Kanisius.

4. InfoDATIN (Pusat Data dan Informasi Kesehatan RI. 2015. Stop Kanker. Jakarta: Kementrian Kesehatan RI, hlm: 3-4.

5. Susanti, Dwi Henny. 2013. Faktor-faktor yang Mempengaruhi Motivasi Perempuan untuk Melakukan Pemeriksaan Skrining Kanker Serviks. Jakarta: FIK-UI.

6. Andrijono. 2012. Kanker Serviks. Jakarta: FIK-UI Divisi Onkologi Departemen Obgyn.

7. Susyandi, dkk. 2010. Hubungan Karakteristik Wanita Usia Subur dengan Motivasi Melakukan Pap Smear di Kelurahan Tugu Depok. Jakarta: FIK-UI.

8. Lestadi, Julisar. 2009. Sitologi Pap Smear Alat Pencegahan dan Deteksi Dini Kanker Leher Rahim. Jakarta: EGC, hlm: 1-4.

9. Sitorus, Sarah Christina A. 2013. Gambaran Pengetahuan Wanita Usia Subur Tentang Deteksi Dini Kanker Serviks di Lingkungan II Kel. Tanjung Gusta Kec. Medan Helvetia. Medan: Fakultas Keperawatan dan Kebidanan Universitas Prima Indonesia.

10. Gaerhart, PA., Human Papillomavirus, emedicine.medscape.com/article/219110overview. (Diunduh pada 21 Oktober 2015, pukul 10.16 WIB).

11. Trisnasari, Debby, Pane, Dorhani. 2008. Hubungan Tingkat Pengetahuan dengan Motivasi Ibu dalam Inisiasi Menyusui Dini. Jakarta: FIK-UI, hlm: 39-42. 
12. Wijayanti, Arum Nur. 2008. Faktor-Faktor yang Mempengaruhi Motivasi Remaja Putri Melakukan Perineal Hygiene (Perawatan Daerah Kewanitaan). Jakarta: FIK-UI, hlm: 37-41.

13. Anggitasari, Fitra. 2009. Hubungan antara Persepsi Wanita Usia Subur (WUS) Mengenai Kanker Seviks dan Perilaku untuk Melakukan Pap Smear. Jakarta: FIK-UI, hlm: 39-41.
14. Wijayanti, Arum Nur. 2008. Faktor-Faktor yang Mempengaruhi Motivasi Remaja Putri Melakukan Perineal Hygiene (Perawatan Daerah Kewanitaan). Jakarta: FIK-UI, hlm: 37-41.

15. Lestari, Peni Puji. 2006. Hubungan FaktorFaktor Ekstrinsik dengan Motivasi Pria Melakukan Vesektomi di Kecamatan Pasar Minggu. Jakarta: FIK-UI, hlm: 50-52. 39 